\title{
The $\mathrm{J}$

VOL. 24, NO. 2

A PRI L

Problems of Operating Large Ships in the Arctic

R. MAYBOURN

The Mystery of Andrea Doria

F. C. BeLL

Precise Underwater Navigation

J. A. Cestone

The Lighthouse Services

D. A. G. Dickens

Manning Reductions and the Cost of Navigation

J. S. MCKENZIE

How to Prevent Collisions

L. OUDET

The Ground in the Western Approaches

C. H. Cotrer

A Method for Predicting the Number of Near Mid-air Collisions in

a Defined Airspace

G. T. A. MAY

The Simple Logic of Radar Avoidance Action

J. V. INGLESBY

Why an Institute of Navigation?

$$
\text { P. HuGON }
$$

FORUM

Traffic Separation in the Dover Strait A REPORT

Collisions in the Dover Strait A. N. BLACK

Dover Strait Routing G. L. MUNDAY

The Case for Revision of Routing W. L. S. HARRISON

Collisions Between Very Large Ships P. C. H. Chissold

Watch Keeping at Sea

P. A. THOMPsON

'Mammoth Vessels and Coriolis Force' G. R. G. LEWISON

Record

Reviews 


\section{THE INSTITUTE OF NAVIGATION}

\section{Patron \\ H.R.H. THE PRINCE PHILIP DUKE OF EDINBURGH, к.G., к.T., о.м.}

OFFICERS AND COUNCIL 1970-71

President

Rear Admiral G. S. Ritchie, c.B., D.s.c.

Vice-Presidents

G. E. Beck

Group Captain D. F. H. Grocott, C.B.E., A.F.C., R.A.F.

Honorary Treasurer

F. A. Haworth

Chairman of the Technical Committee

H. E. Smith

Chairman of the Membership and Fellowship Committee

Captain V. A. M. Hunt, c.B.E.

J. H. Beattie

W. J. Charnley

Captain C. H. Cotter

Captain R. Hart, C.B.E.,

D.s.O., D.s.c*., R.N. (ret.)

S. S. D. Jones

Other Members of Council

Executive Secretary: M. W. Richey, M.B.E.

Captain F. L. Main

Captain R. Maybourn

P. G. Reich

R. B. Richardson

R. Whalley

The Journal of the Institute of Navigation

THE Journal is published quarterly by the Institute and is edited by M. W. RICHEY. It contains original papers contributing to the science of navigation, including those presented at meetings of the Institute together with the ensuing discussion. In addition the Journal includes a record of current navigational work, reviews of important books, and other matters of concern to those interested in navigation. The views expressed in the Journal are not necessarily those of the Institute, or of any organization or department to which the authors may belong. Crown Copyright may be reserved.

The Journal is issued free to all members of the Institute. It is sold to the public at one pound fifty per copy or, by subscription, at six pounds thirty-five per annum (post free) and may be obtained through all booksellers and John Murray (Publishers) Ltd., 50 Albemarle Street, London WI. Back numbers dated two years prior to the current volume may be obtained from William Dawson \& Sons, Ltd., (Back Issues Department), Cannon House, Folkestone, Kent.

Enquiries for advertising space should be addressed to the Institute offices.

The postal address of the Institute is The Institute of Navigation, at The Royal Geographical Society, I Kensington Gore, London SW7. (Telephone: $01-5895021$ ).

Volumes of the Journal can be bound for one pound fifty. The parts should be sent to William Clowes \& Sons Ltd., Dorland House, 14 \& 16 Lower Regent Street, London SW.1. 


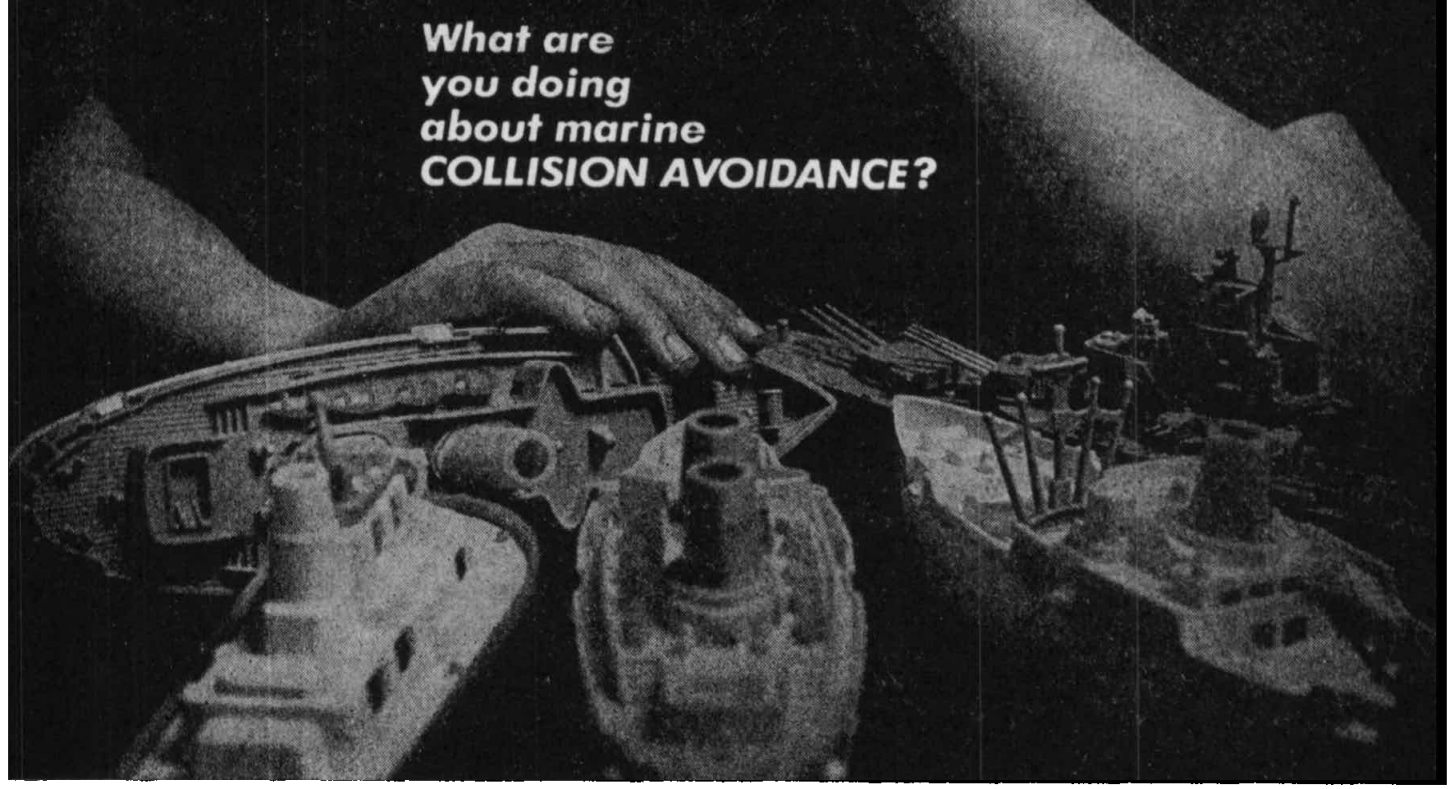

DIGIPLOT (a marine radar aid for automatic anti-collision navigation) does something about it. Digiplot processes signals from conventional radar (either $x$ or $s$ band) and presents it with computed information on a separate screen to give at-a-glance situation appreciation .... Warns of threatening targets. $\square$ Plots and displays up to 40 targets using track-ahead method. $\square$ Instantaneously updates information on clear, flicker-free screen. $\square$ Gives instant digital reading of range, bearing, course, speed, CPA and time-to.CPA for any selected target. $\square$ Instant switching permits viewing situation in true or relative plot modes in head up or North up orientation. $\square$ Trial maneuver capability permits viewing proposed maneuver consequences in speeded up time.

DIRECT INQUIRIES TO:

IOTAON CORPORATION 7 ALFRED CIRCLE BEDFORD, MASSACHUSETTS U.S.A.

CABLE: IOTRON BOSTON.

\section{APPLYING AEROSPACE TECHNOLOGY OF THE'60S . iotron TO 33COLELSIONPREVENTIONN THE '70S}




\section{USEFUL BOOKS ON NAVIGATION}

\section{AND SHIPPING LAW}

\section{MIGHOLLS'S SEAMANSHIP AND MAUTIGAL KMOWLEDgE}

By CHARLES H. BROWN, F.R.S.G.S., Extra Master

$$
\begin{array}{rr}
55 /-(\$ 2.75) & \text { Per post 59/6 (£2.971) } \\
\text { Supplement } 4 /-(20 \mathrm{p}) & \text { Per post 4/6 (221:p) }
\end{array}
$$

BASIG SEAMANSHIP (FOR BEgINIERS AT 8EA)

By COMMANDER PETER CLISSOLD, R.N.R. (Rtd.)

$$
\begin{array}{rr}
21 /-(\$ 1.05) & \text { Per post 22/2 (£1.11) } \\
\text { Supplement } 4 /-(20 \mathrm{p}) & \text { Per post } 4 / 6(22 / \mathrm{p})
\end{array}
$$

RADAR OBSERVER'S HANDBOOK

By WILLIAM_BURGER, M.Sc. (Wales), Extra Master

$$
\text { 42/- (£2.10) Per post } 43 / 6 \text { (£2.17£) }
$$

\section{BUSINESS AND LAW FOR THE SHIPMASTER}

By CAPTAIN F. N. HOPKINS, M.LN., Extra Master

$$
\text { 90/- (\$4.50) }
$$

Supplement 5/- (25p)

Per post $94 / 6$ (\$4.721)

Per post 5/6 (27p)

\section{MERGHANT SHIPPING ACTS}

Revised by CAPTAIN W. V. J. CLARKE, D.S.C.

$$
60 /-(\$ 3.00)
$$

Per post 63/- (23.15)

\section{SHIPBROKERS ANO THE LAW}

By E. J. EDWARD, LL.B. (Lond.)

$$
\text { 30/- (E1.50) }
$$

Per post 31/4 (£1.56ł)

\section{LAW AND PRAGTICE OF 8EA TRANSPORT}

By CAPTAIN L. F. H. STANTON, A.M.Inst.T.

$$
\text { 63/- (23.15) }
$$

Per post 66/- (\$3.30)

Catalogue " $N$ ", gloing further tifles and detalls, free on request.

BROWN, SON \& FERGUSON, LTD., 


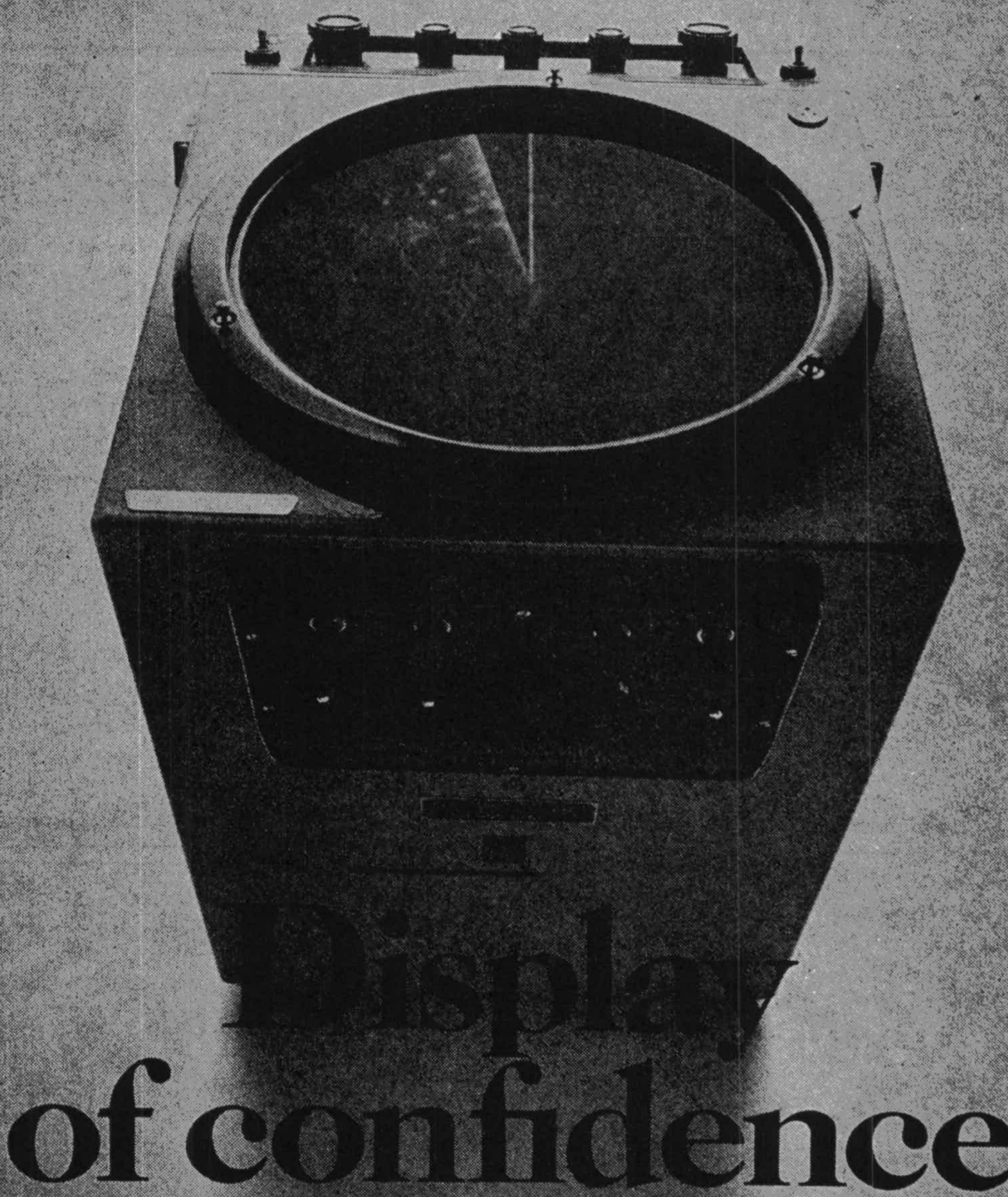

Confidenty, re invite you to see the brightest, clearest radar kisplat: The Kelvith Haghes Series 19. Ask us to show you les ten range scales, from? mile to 64 miles. Its imprayed chitter strpinession. Its $3 \mathrm{~cm} X$ band or $10 \mathrm{~cm} 5$ bom optrationion 9 or 12 displays - with a rahge disorimintion bether than 10 yards ( 9 metres). For the price there's nothing to match it.

\section{Ask fora demonstration}

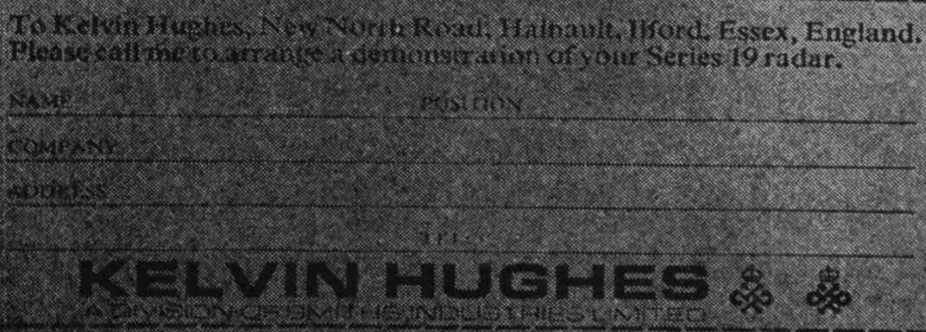




\title{
'NAVIGATION, U.S.A.'
}

Navigarion, the quarterly Journal of the American Institute of Navigation, is available to members of this Institute at a reduced subscription of $f^{2}$ a year. Volume 17, No. 4 (Winter 1970-71) containa the following papers.

APPLICATION OF OPTIMAL CONTROL THEORY TO SATELLITE-BASED OCEANIC

AIR TRAFPIC CONTROL

Stuart H. Starr and Dr. Barry M. Horowite

APPLICATION OF STATISTICAL TBCHNIQUES TO LANDMARK NAVIGATION

9. E. Bennett and 9. C. Hung

SOFTWARE ADVANCES IN AIR TRAFPIC CONTROL DESIGN

Dr. Gene R. Marner

A STRAPDOWN MAGNETIC AZIMUTH DETECTOR

W. A. Shapiro and C. B. Roemer

TIME AND NAVIGATION

Dr. R. L. Durcombe and R. F. Haupt

THB CURRENT STATUS OF AND FUTURE TRENDS IN NAVIGATION TRAINING AT

THE U.S. NAVAL ACADEMY Lieut. F. Richard Whalen, USN

NAVIGATION TRAINING FOR CURRENT SPACE FLIGHTS

Frank Hughes and Charles Floyd

MAN'S FUTURE ROLB AS AN AIRCRAFT NAVIGATOR

Dr. Carl S. Hoffman and Yohn $\tilde{Y}$. Craja

MAN-MACHINE CONSIDERATIONS IN SYSTEM DESIGN FOR ALL-WEATHER,

LOW-LEVEL NAVIGATION

G. V. S. Raju and D. L. Horwitz

USE OF PLANETARIA IN NAVIGATION INSTRUCTION

Major Kenneth W. Brotnoe

THE ROLE OF MAN IN AEROSPACE DEFENSE COMMAND NAVIGATION Major Richard M. Shute, USAF

INERTIAL SYSTEMS AND AREA NAVIGATION IN THE U.S. DOMESTIC AIRSPACE Joseph M. Del Balzo

STAR CHARTS FOR MANNED SPACB FLIGHT

Ted A. Guillory, Gene E. Gentry, and John W. O'Neill

THE INSTITUTE'S PROFESSIONAL FILE

REVIEWS OF RECENT BOOKS

INDEX TO VOLUME 17

\section{THE FENLAND IN ROMAN TIMES}

\author{
Ed. C. W. PHILLIPS
}

*

\section{R. G. S. RESEARCH MEMOIR No. 5}

A unique record of a historic, but fast disappearing, landscape and of Roman settlement in Eastern England. With 24 plates and 18 text figures.

A separate envelope contains 24 maps, many in colour.

Price, including postage and packing, £8.40; R.G.S. Fellows and Members $£ 6.30$. 


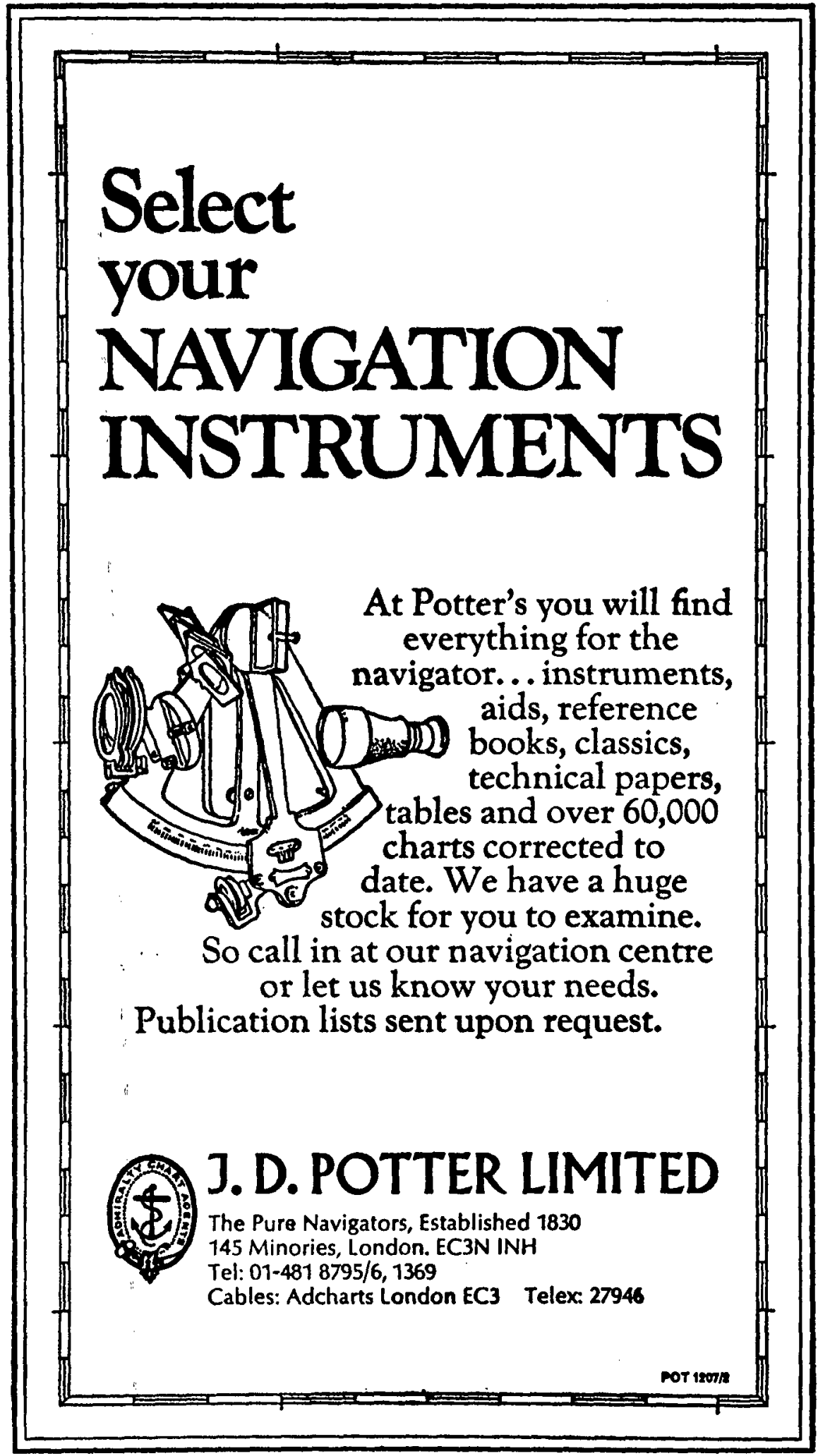




\section{true Plx?}

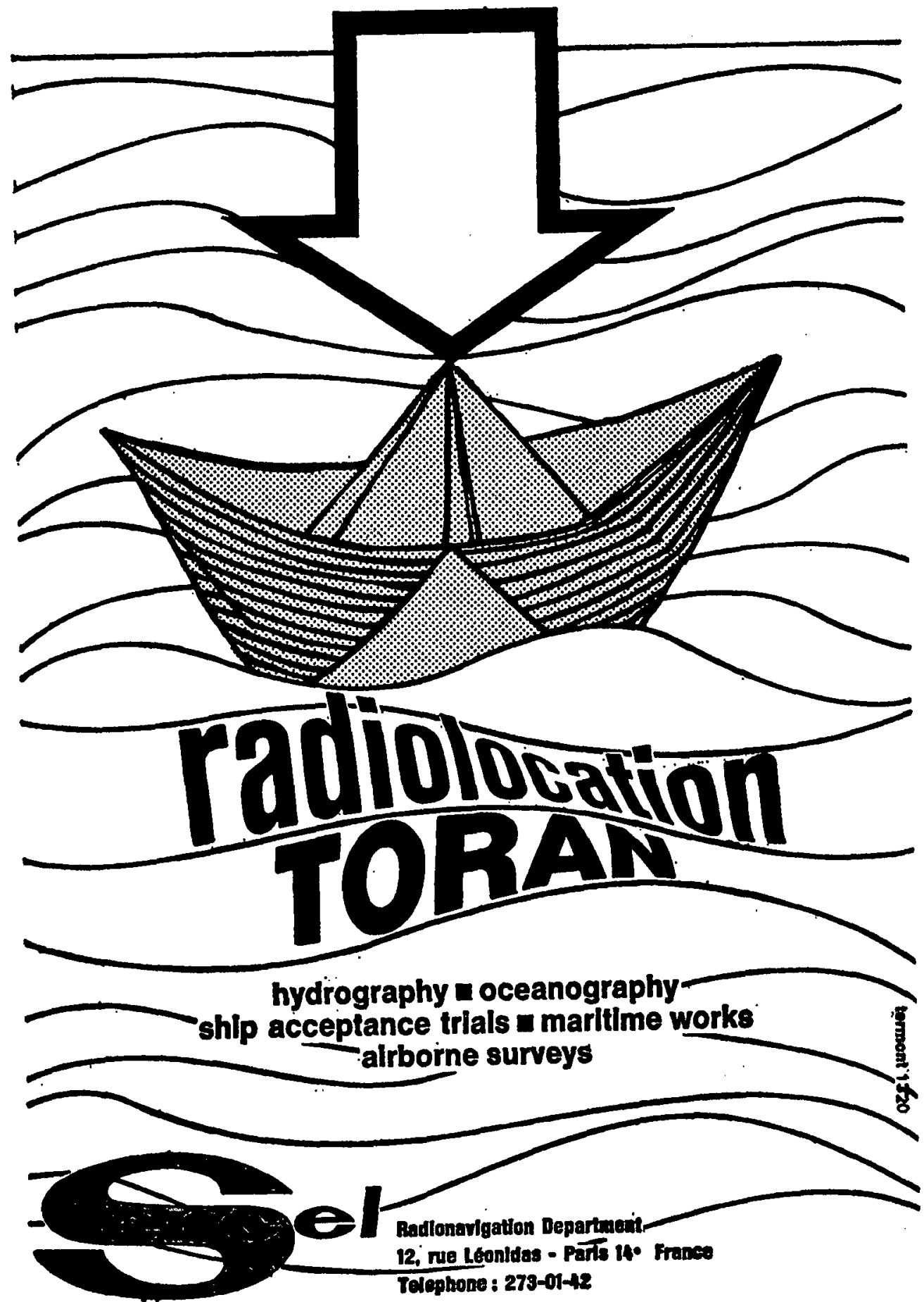




\section{'Electronic Chernikeeff'}

The ideal Log for all Mercantlle purposes-backed by over 50 years actual experience in the design and manufacture of Impeller Logs.

Log makers to the British Admiralty and Overseas Navies for more than 40 years.

1 Accurote and dependable ot all speeds from 1-knot Linear.

2 Suitoble for Ship's Side or Bottom Mouneing $\rightarrow$ no loss of occurocy.

3 Has outputs from True-motion Radar.

4 Stoble Speed Anolog Voltoge Transmission os used by DECCA 'ISIS 300' SYSTEMS etc.

5 The Retractoble Log Tube can be supplied with Remote Control Raising and Lowering System.

6 Low Installation Costs-Simple Maintenonce.

MARCONI-MARINE world wide service is available to users.

Sole Makers
The Submerged Log Bompany (1962) Limited,
565/569 High Road, Ghiswlck, London, W4 3AW, England
Telephone: CHISWICK 01-994 6685/6 Telegrams: CHERLOG LONDON W.4

\section{'NAVIGATION'}

NA VIGATION (Paris), the quarterly Journal of the French Institute of Navigation, is available to Members of the Institute at the preferential subscription rate of $£ 2.00$ per annum. Subscriptions should be addressed to the Institute office in London.

The April 197 i number will include an account, by Borrock and Rider, of the flight trials of the Air Transport Association of America's collision avoidance system; a review of the application of nuclear energy to merchant ships, by David and de Ladonchamp; and a paper on the principles of V.L.F. radio navigation systems. Other features include an article on Arab navigation in the Indian Ocean; a paper on minimum time routes under sail and an appreciation, by Capt. F. J. Wylie, of automatic plotting devices for use with ship's radar.

In addition there is, as usual, a record of events of navigational interest, reviews and correspondence. 


\title{
THE INTERNATIONAL HYDROGRAPHIC BUREAU
}

\section{Avenue Président J. F. Kennedy, MONACO}

\author{
publishes
}

twice a year in January and July, an English and a French edition of

\section{THE INTERNATIONAL HYDROGRAPHIC REVIEW}

This publication contains articles of topical interest on hydrography, hydrographic surveying and related subjects.

Each number contains an average of 160 pages, $18 \times 27 \mathrm{~cm}$., and numerous illustrations.

Price per number 2.50p or $\$ 6$ (U.S.), post free in Europe.

Orders should be sent direct to the Bureau's Headquarters in Monaco, but payments can be made to the Bureau's account at Barclays Bank Ltd., Chief Foreign Branch, 152-156 Upper Thames Street, London, E.C.3. Specify English or French edition when ordering.

A reduction of $25 \%$ on the price quoted is allowed to booksellers. A reduction of $30 \%$ is granted to naval or merchant marine officers of the Bureau's Member States, provided the order is sent direct to the Bureau. 


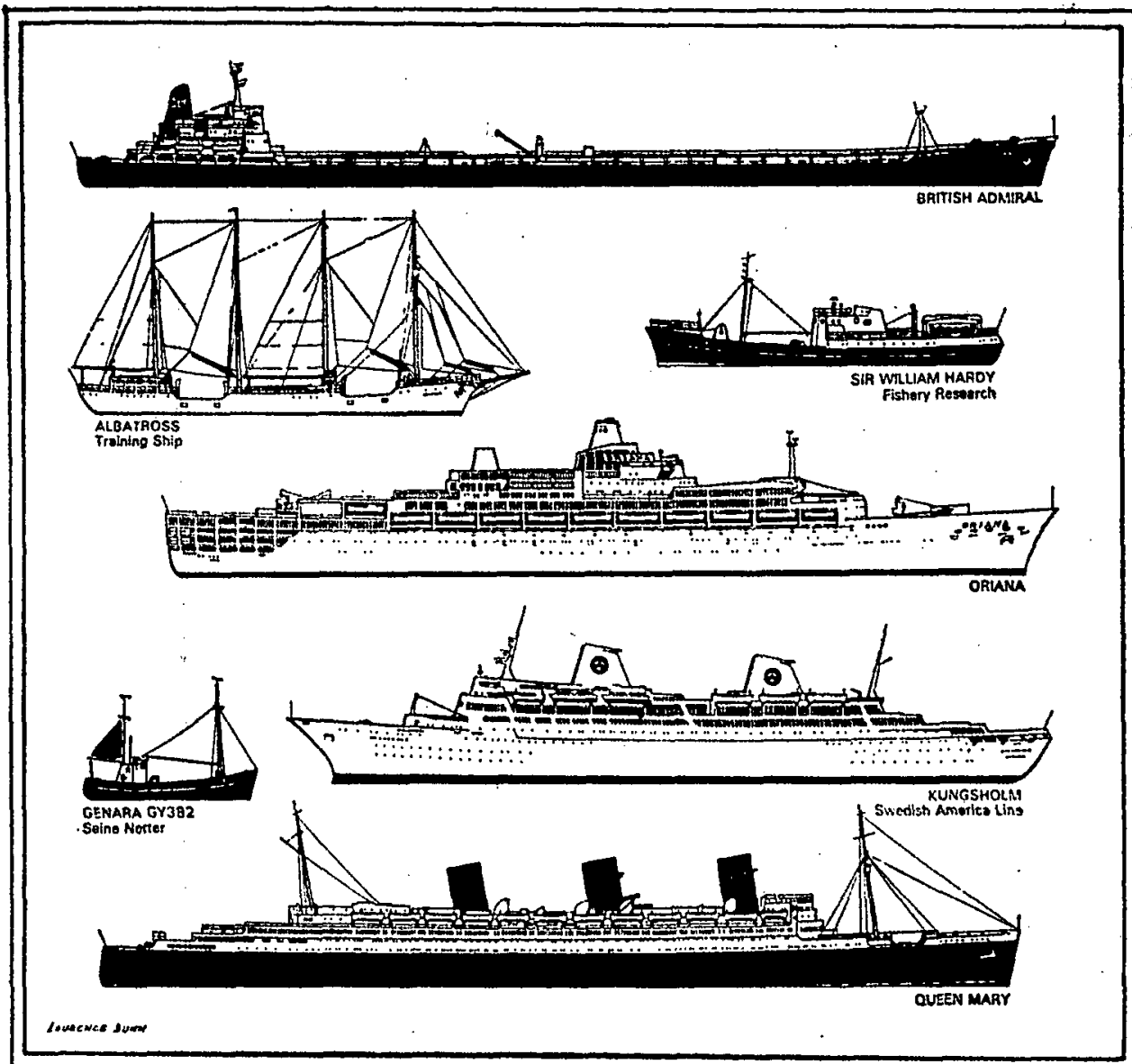

\section{A Growing Tradition...}

Over 15,500 ships of all types and sizes, from the largest supertankers to small fishing vessels, today rely on Decca for accurate navigation and economical operation. Now more and more ships will benefit even more widely as a result of the extensive new coverage now being set up in Australia, the Baltic; South Africa, Japan and the United States.

We are proud to be associated with the wide variety of famous, and not so famous; ships that have relied on the Decca Navigator since it was first introduced commercially over 20 years ago.

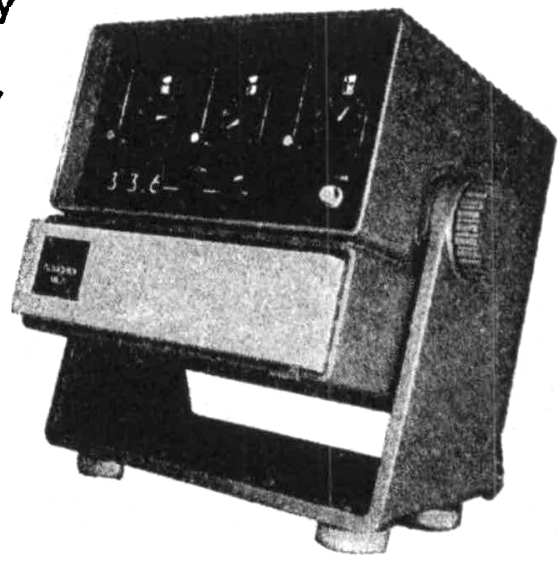




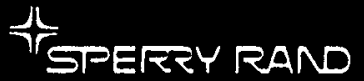

\section{THIS IS TAM OUR VISUAL FENGE} and you're standing into danger

You don't have to navigate the Malacca Straits, the St. Lawrence Seaway or the English Channel to know about collision hazards . . . ship loss statistics tell the story.

This is why the Sperry Marine Systems team has developed TAM - a Threat Assessment Marker which lets ships' officers quickly assess which contacts on the radar screen require his attention. Every contact is covered automatically and each new target generates its own T.AM.

TAM uses a unique 'visual fence' technique as our illustration shows. If the contact crosses the fence towards the centre of the radar picture, you're standing into danger. If it stays outside, then time is on your side.

This is just one of our new systems ... Sperry means business. Systems Business, backed by some 200 service stations worldwide. Means a range of advanced NAVAIDS; new Doppler Sonar equipment for navigation; automatic direction finders and advanced new gyro compasses and autopilots. And, of course, ship stabilisation and a range of radars.

\section{Sperry Rand converts thinking into mutual profit}

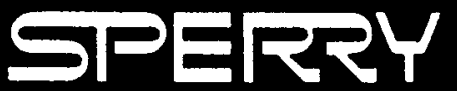

MARINE SYSTEMS

SPEARY MAFINE SYSTEMS DIVISION SPERFY RAND, BAACKNELL, BERKS, ENGLAND TELEPHONE BRACKNELL 3222 

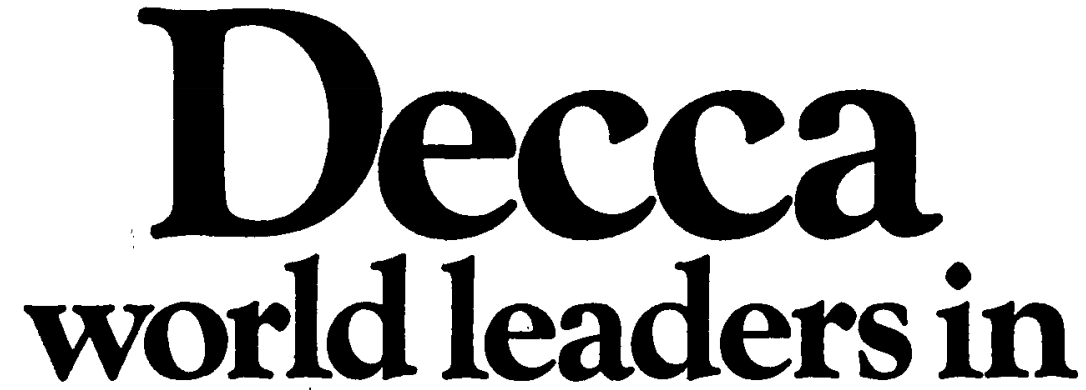

marine electronics

Decca Transar Radar

Decca ISIS 300 Integrated Ship Instrumentation System Decca Navigator System Decca Arkas Automatic Pilot

Decca Radar Limited The Decca Navigator Company Limited Decca House, Albert Embankment London SE1
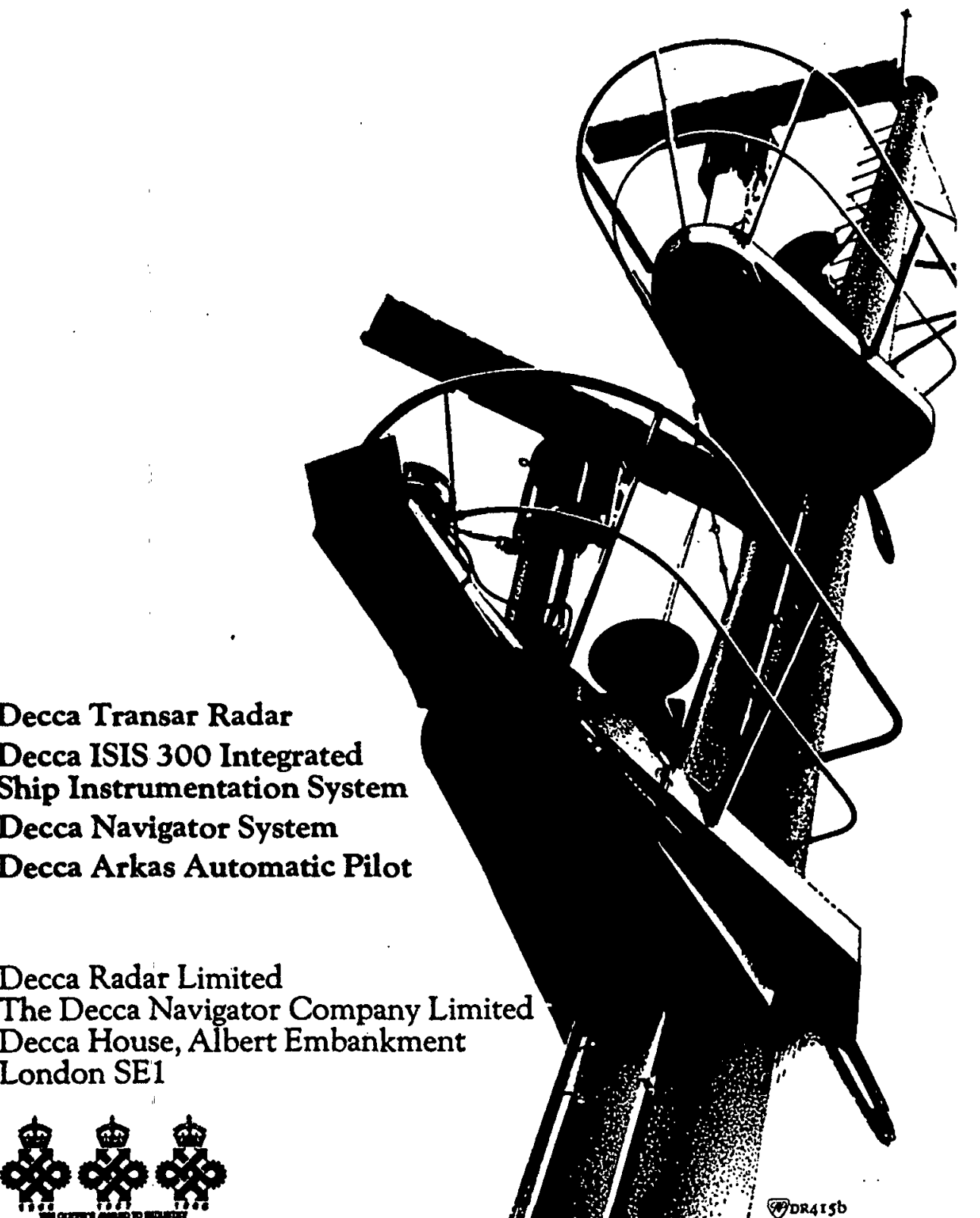


\section{Marconi complete naval communications}

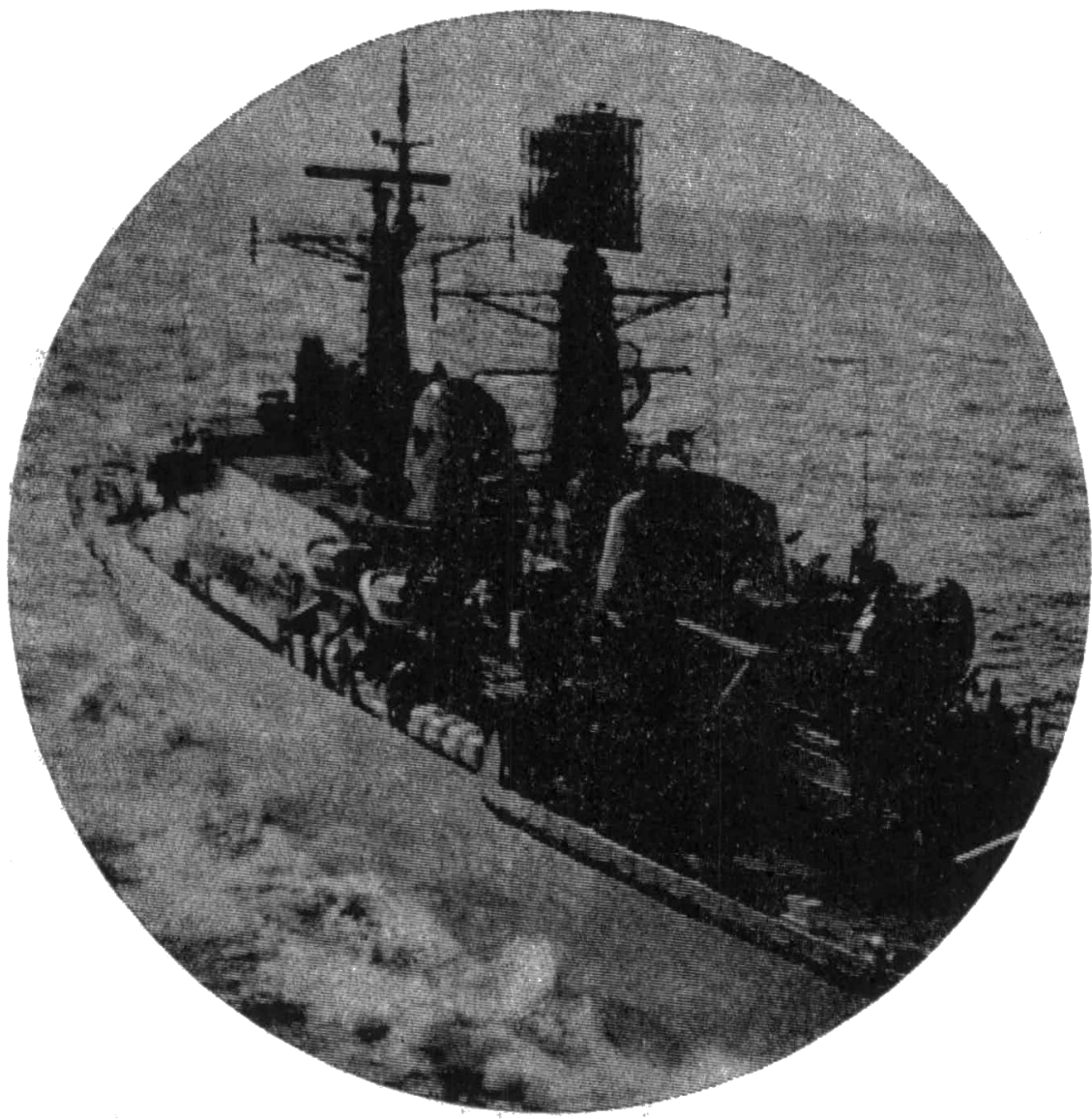

The Marconi comprehensive range of s.s.b/i.s.b naval communications equipment meets all present and foreseeable requirements for voice and automatic telegraphy.

The complete range conforms to Royal Naval standards of resistance to shock, vibration and climatic conditions, and has been NATO codified by the British Defence Department. It is in wide use by the Royal Navy and in the modernization of ten other navies.
Marconi Communication Systems Limited also has a complete range of communications equipment available for shore stations; shipborne, mobile and static space communication earth terminals; digital transmission, and airborne communications.

In addition the Company is able to assist naval departments and shipbuilders with the planning, fitting, testing and tuning of complete ship communications installation.

\section{Marconi Communication Systeme Limitod}

Radio Communications Division, Chelmsford, Essex 


\section{The Institute of Navigation}

\section{The Haven Finding Art}

by E. G. R. Taylor.

'A better book on the art of navigation down to Captain Cook's days has not been written in the English language.' (Mariner's Mirror.)

This new edition contains an appendix by Joseph Needham, F.R.s., on the history of navigation in China. (Hollis \& Carter, 12.50 Members 12.00 plus postage.)

\section{The Use of Radar at Sea}

A Handbook on Marine Radar. (Hollis \& Carter, $£_{3} .50$ )

\section{Observational Errors}

An elementary account of the ideas behind the statistical theory of errors, by E. W. Anderson \& J. B. Parker. (John Murray, 25 P)

\section{The Geometrical Seaman}

An illustrated work on early navigational instruments, by E. G. R. Taylor \& M. W. Richey. (Hollis \& Carter, EI.50)

\section{The Mathematical Practitioners of Tudor and Stuart England}

by E. G. R. Taylor.

(Cambridge University Press, $£_{3.50}$

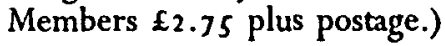

An account of the ideas, instruments and methods in navigation and surveying between 1485 and 1715 with lists of the mathematical practitioners with biographical notes and details of their work.

\section{The Mathematical Practitioners of Hanoverian England}

$$
\text { by E. G. R. Taylor. }
$$

(Cambridge University Press, $\mathfrak{1}_{4} .20$ Members $£_{3} .15$ plus postage.)

This book, a sequel to the carlier volume, takes the story up to 1840 , by which time the independent mathematical practitioner had virtually disappeared, absorbed into the large firm or organization as a consequence of industrial and social change.

\footnotetext{
from The Institute of Navigation

I Kensington Gore, London SW7
} 


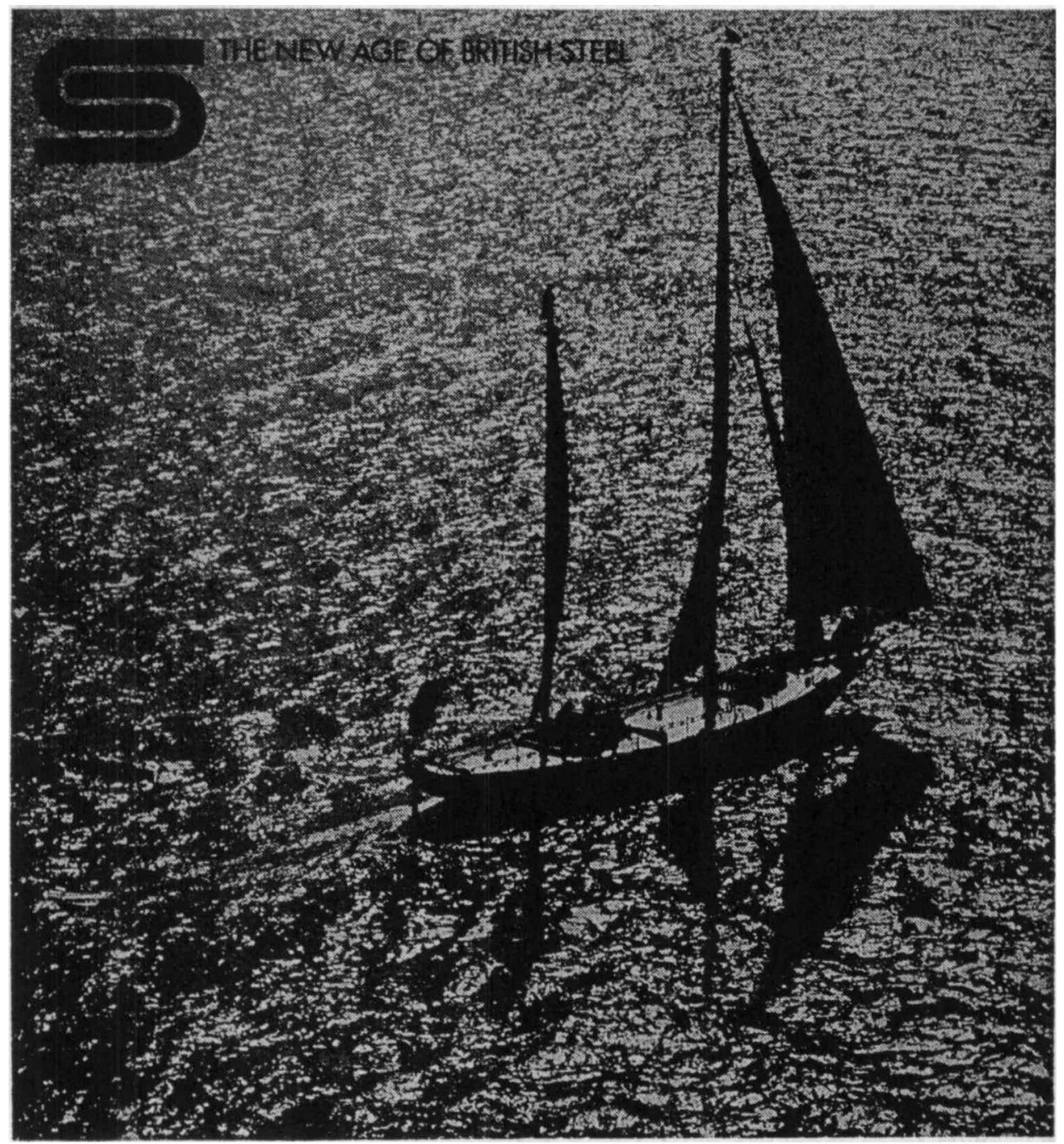

'British Steel' designed by Robert Clark. Built by Philip \& Son, Dartwouth. Length 59 f. Beam ta fl. to ins. Draughs 8 ft. Rig: Bermudan Ketch.

\section{'British Steel'goes round the world}

Over 50 per cent of the value of Britain's exports are steel or steel-containing goods. Last year BSC itself sold some $f_{200}$ million worth of products to all parts of the world $\rightarrow a$ sizeable contribution to the nation's balance of payments - putting BSC among Britain's top four exporters.

To reach its destination British Steel travels by almost every known means, including road, rail, ship and, occasionally, air. And part of the giant Rio Niteroi Bridge in Brazil was recently floated into position across Guanabara Bay.

Now 2 new journey has begun 25 'British Steel'-a specially designed steel yacht - sails round the world, with Chay Blyth (who rowed the Atlantic with John Ridgeway in 1966) at the helm, alone. He will be sailing from East to West-against the prevailing winds and currents. This is the first time that a single-handed, non-stop round trip has been attempted "uphill.

Steel was Chay Blyth's own choice for his yacht. "Its unique combination of lightness and toughness makes it the best material for the job", he says. In addition to the hull, most of the boat's fixturesend fittings are steel. So is the rigging and much of the equipment which he will take with him.

'British Steel' sails round the world, close-hauled to windward. And the spirit and challenge of this unique adventure symbolise the new age of British Steel. 


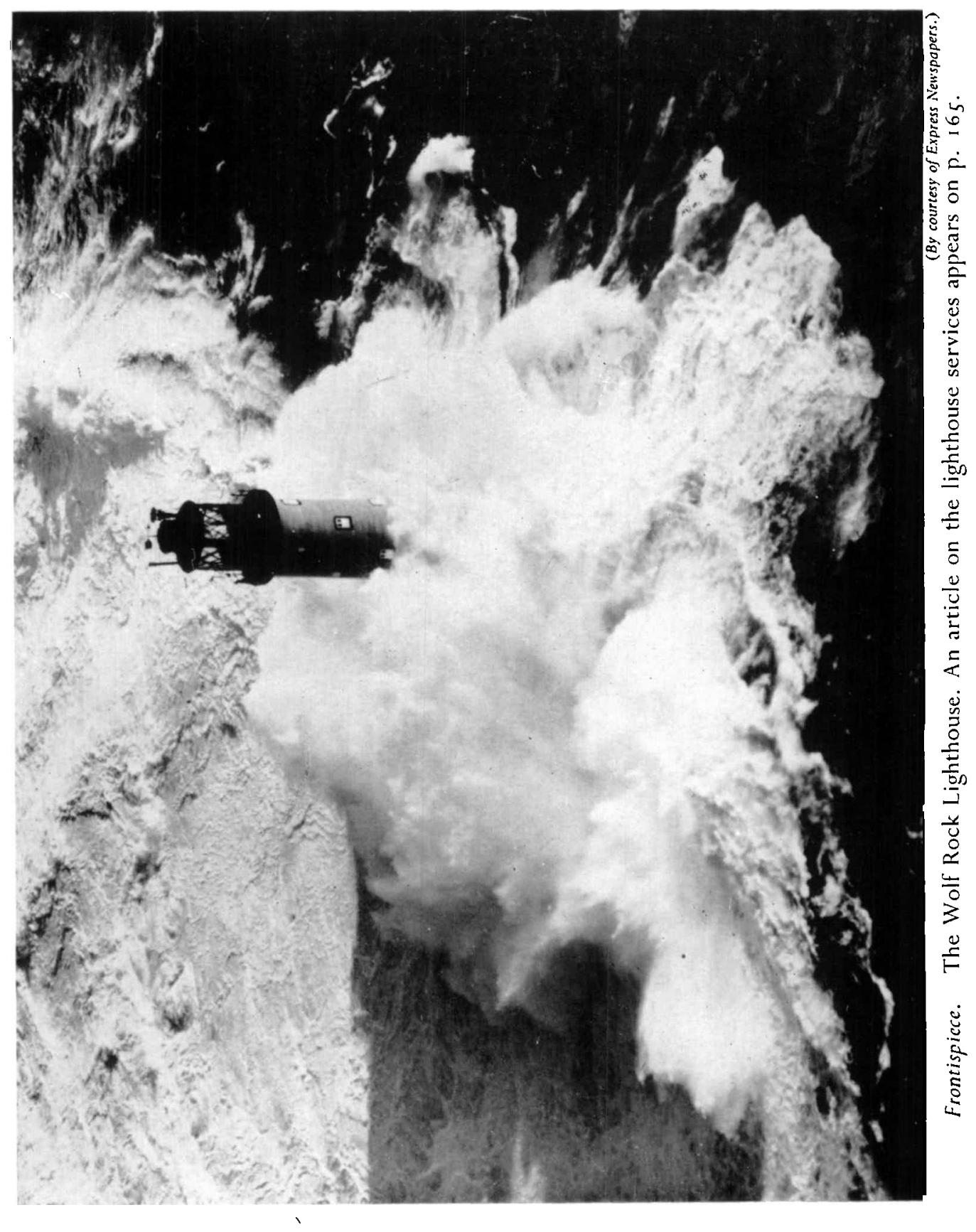

